\title{
製品検查処理の並列分散化に関する一手法
}

\author{
白石 洋一*, 岡田 佑樹**
}

\section{A Product Testing Method on a Parallel and Distributed System}

Yoichi SHIRAISHI* and Yuki OKADA**

\footnotetext{
* 群馬大学 [.学部情報 「学科（干 376-8515 群馬県桐生市天神町 1-5-1）

**株式会社東芝テック（テ 411-8520 静阊県三島市南町6-78）

*Department of Computer Science, Gunma University (1-5-1 Tenjin-cho, Kiryu-shi, Gunma 376-8515)

**Toshiba Tec, Corp. (6-78 Minami-cho, Mishima-shi, Shizuoka 411-8520)
}

\begin{abstract}
概要 複数台の検査データ取得装置之複数台の検査データ処理装置がネットワークで結合された製品検查処理の並列分散 化を考える。1台の倹査デー夕取得装罟からは, 一定時問ごとに検査デー夕が連続的に得られ, その検査デー夕を 1 台の検査 デー夕処理装置に送信して処理する。検査データ生成時開, 検査デー夕送信時開, 検査デー夕処理時間がミリ秒単位と非常に 小さい条件のもとで, 検査デー夕を滞ることなく, かつ負荷均等化を目標に検査デー夕処理装置に割り当てる。本論文では, この問題を解決するための製品検査処理システムと検査デー夕割り当て手法について述べる。本システムと提案手法を実デー 夕に対して評価した結果，ある台数以上の検査デー夕処理装置の屯とで，逐次処理に刘して，処理時䦎を $72 \%$ 削減し，検査 デー夕処理装置の所劣メモリ焄を $99.7 \%$ 削減した。さらにランダムに検査デー夕を処理装置に割り当てるナ法と比較して，そ れぞれを，19\%，98.8\%削減した。
\end{abstract}

\begin{abstract}
This paper deals with a product testing method on a parallel and distributed system that consists of several test data acquisition devices and several test data processing devices. The test data acquisition device depicts data in a constant period and the data are sent to the test data processing device. In this system, acquisition and transmission of the test data takes several tens of milliseconds, and test data processing requires about a hundred milliseconds. In this environment, every test data acquisition must be assigned to a data processing device without blocking the next acquisition, while balancing the load among processors. This paper describes and discusses a testing system and a load balancing method. This system and the suggested method were evaluated against actual testing problems. As a result, the processing time was reduced by $72 \%$ and the required amount of memory was reduced by $99.7 \%$, compared to a sequential process in which a certain number of data processing devices are available. Moreover, processing time and required amount of memory were reduced by $19 \%$ and $98.8 \%$, respectively, compared with a random load balancing method.
\end{abstract}

Key Words: Product Testing, Parallel, Distributed, PC Cluster

\section{1. 緒 言}

製品の検査処理は，製品の機能と性能を保証する上で重 要な処理であり, 個々の製品を個別に検査する必要がある ことから，製品数に依存した多大な処理時間を要する。今， Fig. 1 に示す製品検査装置の構成を考える。本論文で取り 扱う製品検査では，まず，テスタで製品の検査デー夕を採 取する。これをタスク (task) と呼ぶ。通常, テス夕は組込 み計算機, または外付けの計算機に接続される。これらの 計算機では, 例えば压縮処理など, 検査デー夕の初期処理 を行う。並列処理における議論のために，この計算機を本 論文ではディスパッチャ (dispatcher) と呼ぶ。タスクはディ スパッチャからネットワークを経由してサーバに送信され, サーバ上で検査処理を受ける。タスクの生成時間はサーバ 
クを保存したあと，ディスパッチャは次のタスクの処理を 行うことができる。

本論文では，特にタスクの生成時間，タスクのネット ワークを介した送信時間，およびタスクの検査処理時間と が非常に近い検査処理を取り扱う。例えば具体的に，夕ス クのサイズが 200 キロバイト $(\mathrm{KB})$, 生成時間が 40 ミリ秒

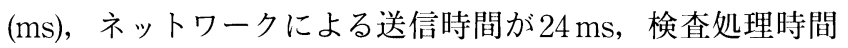
が $105 \mathrm{~ms}$ で，これらのそれぞれの処理時間が非常に近いと いうことが特徴である。また， 1 製品当たり，この検查処 理を 1,000 回繰り返す。

Fig. 1 は，この検査処理を行うために，テス夕 1 台とディ スパッチャ 1 台，およびサーバ1台をネットワークで直結 した 2 セットの検査装置からなる構成を示している。この 装置構成による検査処理では, 次の問題点が発生する。(1) ディスパッチャ1台に対してサーバ1台の構成では, 検查 処理がサーバの能力に支配され, 上の例では, 夕スク生成 時間が $40 \mathrm{~ms}$ であるのに対して全体の検査処理時間が $105 \mathrm{~ms}$ になる, (2)キューのサイズが増大し, サーバの記憶 装置を増設する必要がある, (3)サーバのメインテナンス中 には，テスタとディスパッチャを停止させる必要があり， 検查処理の効率を低下させる。特に上の例では, シミュ レーションによれば(2)のキューの長さは最大 618 となり， 単にタスクを一時的に格納するだけで，少なくても $200 \mathrm{~KB} \times 618=123.6 \mathrm{MB}$ のメモリを要する。ディスパッチャ にもキューを設置して送信前のタスクを保持することも可 能である。しかしその場合, サーバがタスクデータ受信可 能状態になり，タスクデータ取得中にディスパッチャとテ スタに割り込みをかけてタスクデータの送信を要求するこ とは，テスタが正確なデー夕を取得することに悪影響を与 える可能性があり, 通常は禁止される。さらに, メインテ ナンスを除いて製品検査処理は継続することが多いため, これらの問題点は検査処理の効率を低下させる。また, 製 品検査処理のスループットを上げるためには, テス夕, ディスパッチャ, およびサーバ一式の増設が必要なため, 投資効率が低い。

本論文では，これらの問題点を解決するために検査処理 の並列分散化を検討する。基本的な並列分散手法のアイ ディアはすでに述べた ${ }^{1)}$ が, 本論文ではその手法のより詳 細な説明と実験・評価結果を述べる。本論文で検討する検 査装置の構成を Fig. 2 に示す。Fig. 2 の装置構成はFig. 1 の 装置構成において, 検査処理を実行するサーバをディス パッチャに複数台接続して, タスクの検査処理を並列分散 させる。この装置構成と提案する並列分散化アルゴリズム によって, 以下で示すが, 上の (1)の問題点は 1 製品の夕ス ク生成時間合計の 40 秒程度に短縮でき, (2)のキューのサ イズを半減させることができる。また，(3)のメインテナン ス性の向上は明らかであり, さらに製品検査装置の処理能 力を高めるためには, ディスパッチャ数に対するサーバ数

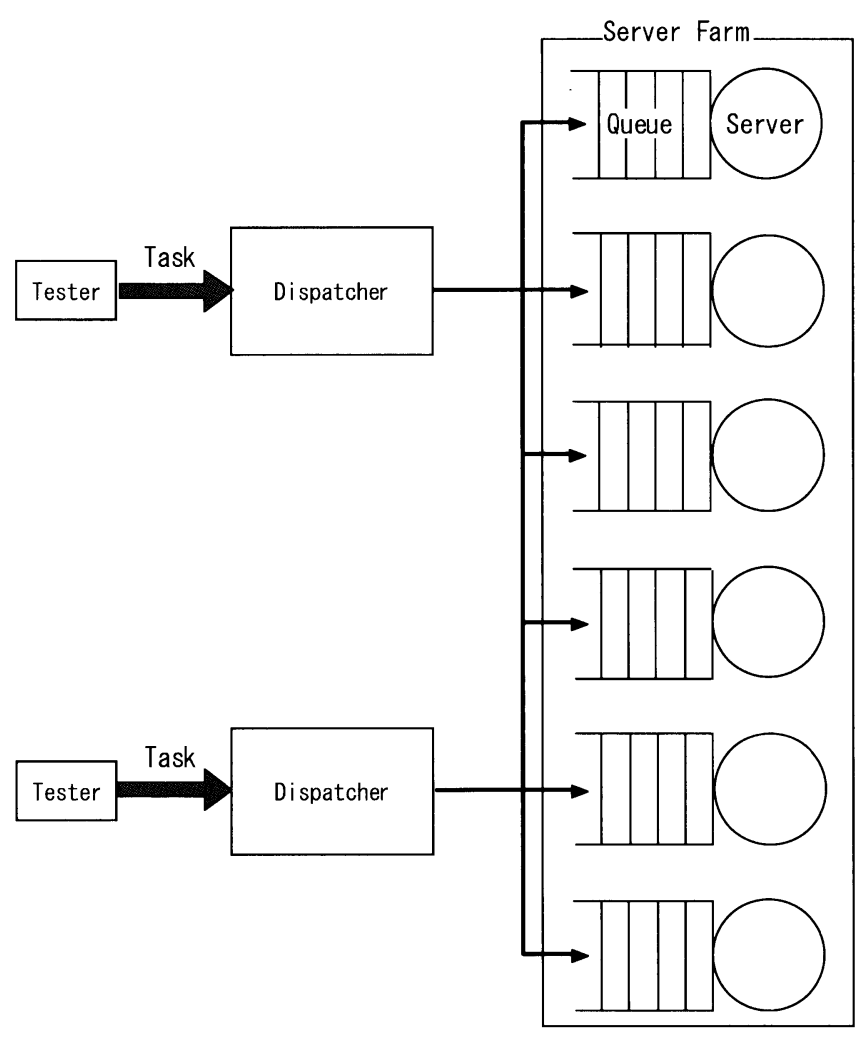

Fig. 2 Multiple task assignment architecture

のみを実験的に得られる最適数まで増設すればよい。

従来より，本論文で取り扱うタスク割り当て問題につい てはさまざまな研究が行われてきている。それらは，例え ば1台のディスパッチャとサーバファームが接続された装 置構成のもとで, タスクをサーバに割り当てる問題として 設定されている2) 5)。これらは，アクセスが集中するウエ

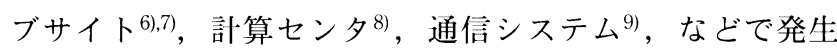
する問題である。各サーバはキューを持ち, FCFS (FirstCome-First-Served)に従ってタスクの処理を行い, サーバ間 での情報交換は行わない3)。また，夕スクの処理は途中で 中断して再開することはできない。ディスパッチャはキュー を持たず，ある夕スクの割り当てと送信処理が終了してい ない場合，ディスパッチャに次のタスクは入力できない4。 しかしディスパッチャが 1 台からなる並列分散化問題と, 本論文のように複数台からなる問題では, 問題の性質が異 なる。サーバを共有するため，ディスパッチャがサーバの 状態を正確に把握できないためである。また，これまでに 提案されてきた並列分散手法では，ディスパッチャとサー バ間の通信時間を無視して5),10)，タスクデータサイズが可 変の場合にどのサーバにタスクを割り当てるかを検討して (る4)。これは, 従来, サーバにおける処理時間と所要义 モリ量が大きい問題を並列分散処理によって解決するとい う動機で研究が行われることが多く, サーバでの処理時間 に比べれば，通信時間は無視できるほど小さいためである。 さらに，本論文のような実際の並列分散化問題に対して， 
実装方法における詳細な課題を取り上げた研究は，われわ れが知る限り報告されていない。

本論文では，Fig. 2 に示すように，2台以上のディスパッ

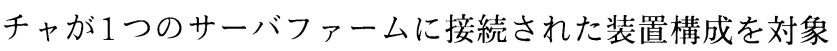
とし，これを多重タスク割り当て問題と呼ぶ。ここでは, 先の具体例に示したように, タスクの生成時間間隔とサー バでの処理時間の差が数倍程度と小さく, またタスクデー 夕の送信時間が夕スクの生成時間の半分程度, 混雑時には 1.5 倍程度と, ネットワークには常にデータが流れ, ほとん どビジー状態であるという環境を想定する。本論文では, まず，提案する多重タスク割り当てアルゴリズムに基づい たタスク割り当てシステムをPCクラスタにより構成する。 続いて, 本システムを $\mathrm{MPICH}^{11,12)}$ を用いて実装し実験評価 した。その結果, 提案アルゴリズムにより, あるサーバ数 のもとで検查処理をタスク生成時間近くにまで削減可能な ことを確認した。また，提案する多重タスク割り当てアル ゴリズムとランダムタスク割り当てアルゴリズムの性能を 比較し, 提案アルゴリズムのアプローチの有効性を確認し た。

本論文の構成は以下の通りである。まず，2節において 実際に解くべき多重タスク割り当て問題を定義する。次に 3節に扔いて，多重タスク割り当てシステムを提案し，そ の上で動作する多重タスク割り当てアルゴリズムを示す。 4節では，実際の問題を設定して提案システムとアルゴリ ズムに対する実験と評価を述べる。最後に5節において本 論文をまとめる。

\section{2. 多重タスク割り当て問題}

本節では，多重タスク割り当て問題を定義する。

定義 1 割り当て

$S$ をーバファーム，Kをある時間区間において生成さ れたタスク集合とする。割り当て $a$ とは，夕スク集合 $K$ か らサーバファームSの中への 1 対 1 写像である。すなわち, $a: K \rightarrow S, a\left(\boldsymbol{k}_{i}\right)=\boldsymbol{s}_{j}, \boldsymbol{k}_{i} \in K, \boldsymbol{s}_{j} \in S 。$

\section{定義 2 待機回数}

$D$ をディスパッチャの集合とする。ディスパッチャ $\boldsymbol{d}_{g} \in D$ が夕スク $\boldsymbol{k}_{i+1}$ を割り当て $a$ によってサーバ $\boldsymbol{s}_{j}$ に送信する際 に, $\boldsymbol{d}_{g}$ 上で直前に割り当てを決定したタスク $\boldsymbol{k}_{i}$ のデータの 送信が完了していない回数を待機回数 $\boldsymbol{w}_{g}^{a}$ 之呼ぶ。

タスク割り当て問題では，あるディスパッチャ上の夕ス クをサーバに割り当てる際に，そのディスパッチャ上の直 前のタスクの送信が完了していなければならない3)。しか し実際の問題では，ネットワークの状況などによって必ず しも送信が完了するとは限らない。したがって, この条件 が満たされない回数を待機回数と定義し，ある時間区間に おいて待機回数合計を最小化することを目的関数の 1 つと する。待機回数 $\boldsymbol{w}_{g}^{a} \neq 0$ の場合には，ディスパッチャが夕ス クデー夕取得中に直前のタスクを送信可能となっても，そ
のタスクデータ取得を途中で中断することができず，その 時点では直前のタスクデータを送信することができない。 したがって, 現在のタスクデータ取得完了後に直前の夕ス クデー夕を送信する。タスクデータ生成時間から見ると， これは全タスク数合計が $\boldsymbol{w}_{g}^{a}$ 個增大することに相当する。

定義 3 サーバの負荷

サーバ $\boldsymbol{s}_{j} \in S$ の負荷は $\boldsymbol{L}_{j}=\left|\boldsymbol{K}_{j}\right| \boldsymbol{t}_{p} \boldsymbol{v}_{j}$ で表す。 $\boldsymbol{K}_{j}, \boldsymbol{t}_{p}$, および $\boldsymbol{v}_{j}\left(0<\boldsymbol{v}_{j} \leq 1\right)$ は，それぞれ，サーバ $\boldsymbol{s}_{j}$ に割り当てられた夕ス クの集合, 基準サーバで処理した場合の夕スク処理時間, および基準サーバに対するサーバ $\boldsymbol{s}_{j}$ の相対処理速度である。

従来の夕スク割り当て問題では, サーバの処理速度はす べて等しいと仮定していた3)。しかし，本論文で取り扱う 多重夕スク割り当て問題では，この条件を仮定できない。 サーバ処理速度はすべて等しくとも, 別のディスパッチャ がサーバに別のタスクを割り当てているため，そのサーバ の処理速度は他よりも低下する。

以上の定義をもとに, 本論文で対象とする多重タスク割 り当て問題を定義する。この問題を取り扱った研究は, 著 者らの知る範囲では現在までに報告されてない。

定義 4 多重夕スク割り当て問題

入力：タスクの入力間隔 $\boldsymbol{t}_{g}$ (全ディスパッチャに対して 共通), タスクの処理時間 $\boldsymbol{t}_{p}$ （基準とするサーバ上での時 間), タスクデータ送信時間 $\boldsymbol{t}_{m}$, ディスパッチャ集合 $D$, あ る時間区間における生成タスク集合 $K$, サーバファーム $S$, サーバ $\boldsymbol{s}_{j}$ の基準サーバに対する相対処理速度 $\boldsymbol{v}_{j},(1 \leq j \leq|S|$, $\left.0<\boldsymbol{v}_{j} \leq 1\right)_{\text {。 }}$

出力：タスクのサーバへの割り当て,

$$
\begin{aligned}
& a\left(\boldsymbol{k}_{i}\right)=\boldsymbol{s}_{j}, \quad \boldsymbol{k}_{i} \in \boldsymbol{K}, \quad \boldsymbol{s}_{j} \in \boldsymbol{S}, \\
& \boldsymbol{K}=\cup_{j} \boldsymbol{K}_{j}, \quad \boldsymbol{K}_{i} \cap \boldsymbol{K}_{j}=\phi \quad(i \neq j), \\
& \boldsymbol{K}_{j}=\left\{\boldsymbol{k}_{i} \mid a\left(\boldsymbol{k}_{i}\right)=\boldsymbol{s}_{j}\right\}
\end{aligned}
$$

目的関数 :

サーバの負荷均等化（負荷分布の標準偏差最小化）: $\min _{a} F_{1}$,

$$
\text { ここで, } \quad F_{1}=\sqrt{\frac{|S| \sum_{j=1}^{|S|} L_{j}^{2}-\left(\sum_{j=1}^{|S|} L_{j}\right)^{2}}{|S|(|S|-1)}} / \sum_{j=1} L_{j}
$$

待機回数合計最小化: $\min _{a} F_{2}$,

$$
\text { ここで, } \quad F_{2}=\sum_{g=1}^{|D|} w_{g}^{a}
$$

多重夕スク割り当て問題は, 式(1) と式(2)に示す目的関 数, $F_{1}$ と $F_{2}$ を最小化する多目的最適化問題である。

\section{3. 多重タスク割り当てシステムと多重タスク割り当 てアルゴリズム}

本節では，2節で定義した多重タスク割り当て問題（定 


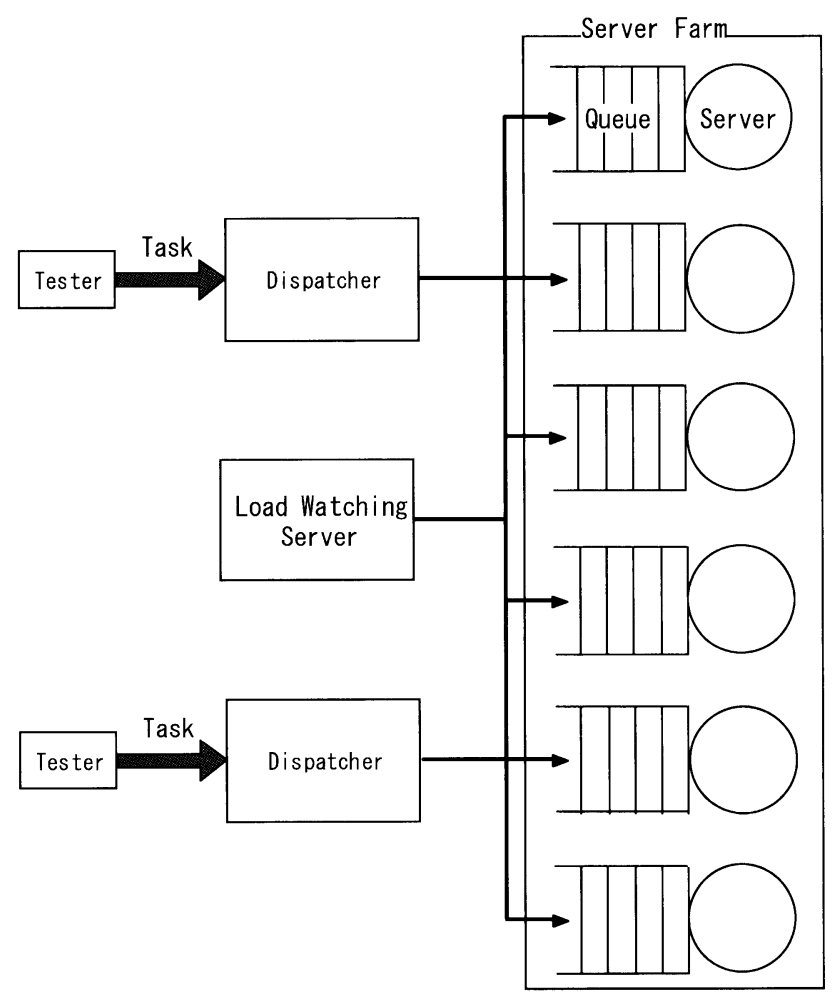

Fig. 3 Multiple task assignment system

義4）を解くための多重夕スク割り当てシステム, 多重夕 スク割り当てアルゴリズム，およびその上で実行する負荷 分散アルゴリズムについて述べる。

\section{1 多重タスク割り当てシステム}

提案する多重夕スク割り当てシステムをFig. 3 に示す。 これは, Fig. 2 に示すディスパッチャとサーバファームか らなる構成に負荷管理サーバを追加したシステムである。

\section{2 多重タスク割り当てアルゴリズム}

\section{【アルゴリズムの基本的な考え方】}

定義 4 に示したように，多重夕スク割り当て問題の目的 関数は, サーバの負荷均等化之待機回数合計最小化である と定義した。サーバの負荷均等化を行うために，Fig. 3 に 示したように負荷管理サーバを設定して動的にサーバの負 荷管理を行い，ディスパッチャからの問い合わせに対して， 割り当てるべきサーバを指示する。負荷管理サーバを導入 したのは，ディスパッチャで負荷管理を行うとタスクデー 夕生成に割り込み処理が必要になり，先に述べたように夕 スクデータ生成に不具合を及ぼすこと， タスクデータの サーバへの送信とサーバからの負荷状況報告の通信が衝突 して待機回数の增大を招くこと，および専用サーバとして 独立させることでディスパッチャからの問い合わせに対し て，即，割り当てサーバを返信するためである。ネット ワークはタスクデータの送信だけで常にビジー状態である ことを仮定するため，待機回数を最小化するためには必要 最小限の情報の収集にとどめる。待機回数合計最小化は, 次に示す夕スクの処理手順に反映させることで試みる。

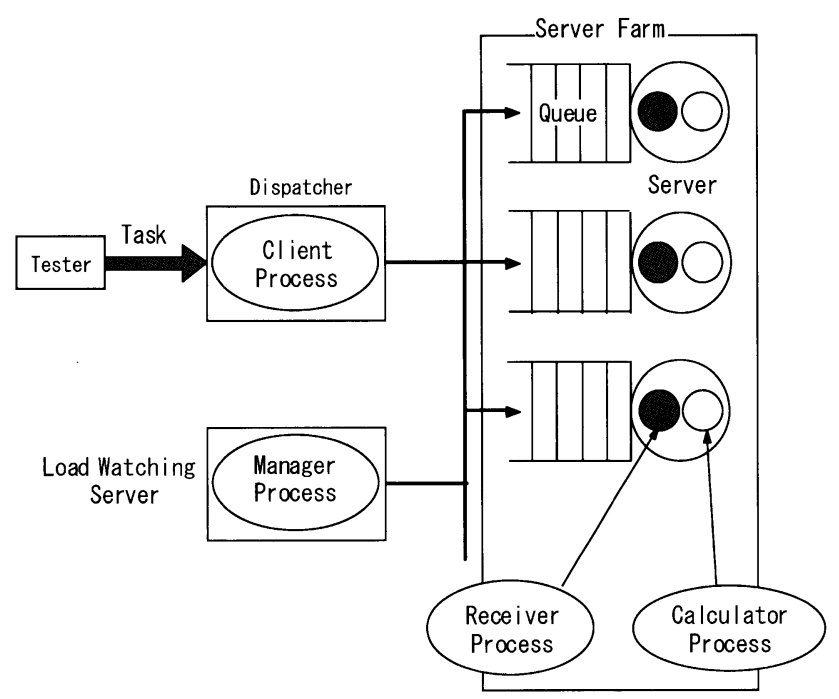

Fig. 4 Processes on each machine

以下では，各マシン上のプロセス間の動作を述べる。Fig. 4 に示すように各ディスパッチャ上にクライアントプロセ ス, 負荷管理サーバ上にマネージャプロセス, 各サーバ上 にレシーバプロセスとカリキュレータプロセスを生成する。

Fig. 5 にある時間区間に生成された $|K|$ 個のタスクを処 理する場合の各プロセスの動作を示す。

【タスク $\boldsymbol{k}_{i}$ の処理手順】

(1)〜(7)を $|K|$ 回繰り返す：

(1) クライアントプロセスは， タスク $\boldsymbol{k}_{i}$ を処理すべき サーバをマネージャプロセスに問い合わせる，

(2) マネージャプロセスは(1)の問い合わせに対して, サーバファーム内の 1 つのサーバ $\boldsymbol{s}_{j}$ を決定する，

（3）クライアントプロセスは(2) で決定したサーバ情報 $\boldsymbol{s}_{j}$ を受け取る，

(4) クライアントプロセスはサーバ $\boldsymbol{s}_{j}$ 上のレシーバプ ロセスにタスク $\boldsymbol{k}_{i}$ を送信し，レシーバプロセスはこ れを一時保存する，

レシーバプロセスとカリキュレータプロセス間で (5) (7) を繰り返す：

(5) サーバ $\boldsymbol{s}_{j}$ 上のカリキュレータプロセスは, タスク データの送信要求をレシーバプロセスに送信する,

(6) レシーバプロセスはカリキュレータプロセスの要 求に従って，タスク $\boldsymbol{k}_{i}$ のデー夕を送信し，キューか らそのデータを削除し，そしてマネージャプロセス に更新後のキューの使用量を送信する,

(7) カリキュレータプロセスは, タスク $\boldsymbol{k}_{i}$ を処理し, 結果を保存する,

タスクデータ処理結果の回収処理として (8) と (9)を実行 する：

（8）マネージャプロセスは，受け取った終了信号をす ベてのレシーバプロセスにブロードキャストする,

(9) カリキュレータプロセスは，レシーバプロセスか 


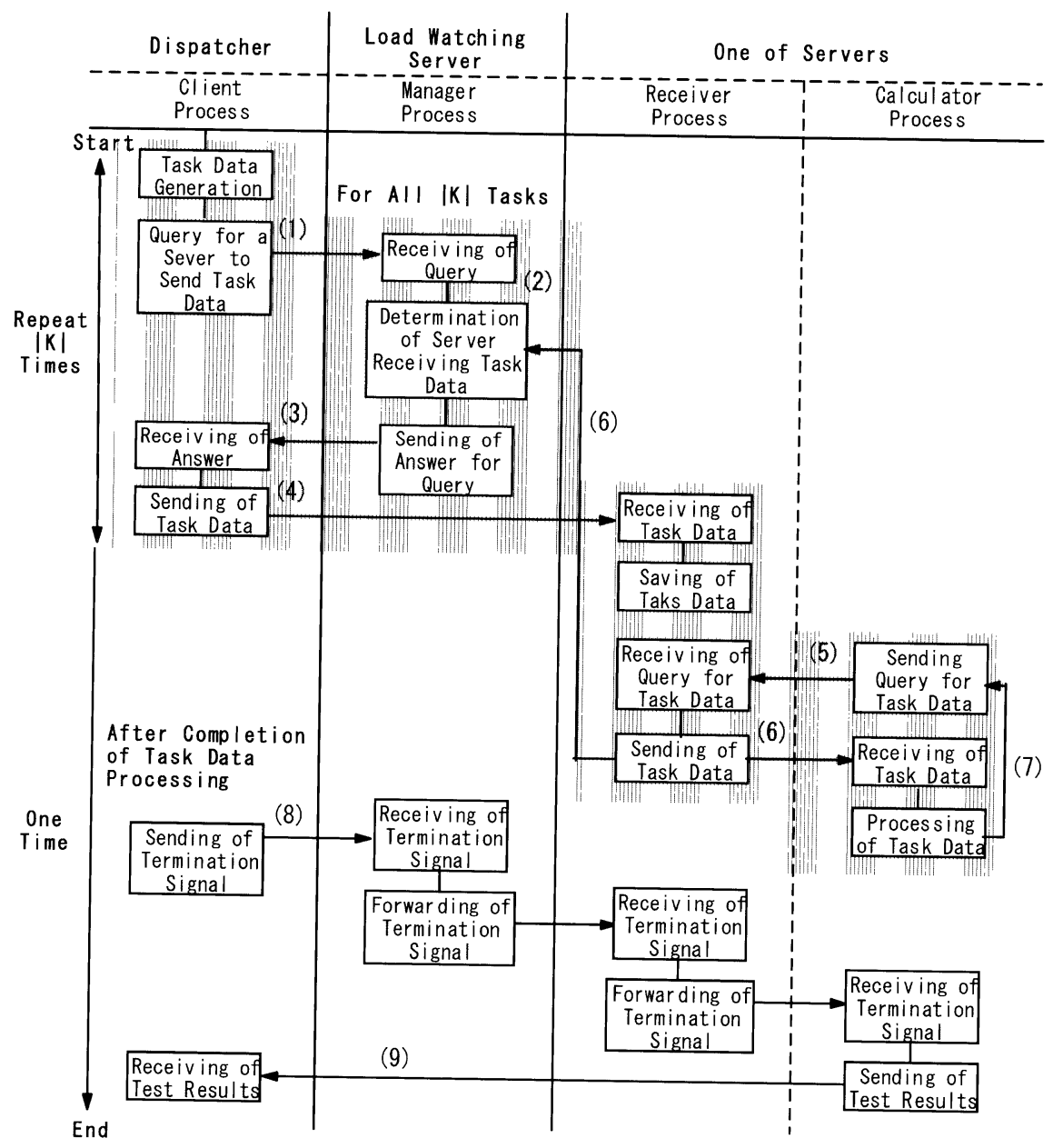

Fig. 5 Timing chart of processes for a set of $|K|$ tasks; The client process of a dispatcher generates a task and it is sent to a server determined by the manager process of the load watching server. Then, the task is received by the receiver process and tested by the calculator process of the server. After generating $|K|$ tasks, the client process sends a termination signal to the load watching server and it is broadcasted to all servers. After receiving he termination signal, the calculator process sends test results to the corresponding client process.

らのタスク終了信号を受信後, 対応するクライアン トプロセスに処理結果を直接送信する。

タスク $\boldsymbol{k}_{i}$ の処理手順に関して説明する。(1)においてクラ イアントプロセスがタスクを割り当てるべきサーバをマネー ジャプロセスに問い合わせるのは，【アルゴリズムの基本 的な考え方】で述べたように，あるディスパッチャ上のク ライアントプロセスがサーバの負荷状況を管理できないた めである。サーバ上には, タスクデー夕受信専用のレシー バプロセスと, タスクデータ処理専用のカリキュレータプ ロセスを生成する。これらを1つのプロセスとすると，サー バに抽てタスクデータ処理中にタスクデータ受信要求が 発生した場合, タスクデータ処理を中断することができず, タスクデータ受信の待ちを発生させるためである。この待 ちが発生するとある時間後にその夕スクデータを再送信し なければならず，結果として待機回数を増大させる。レ シーバプロセスはカリキュレータプロセスの要求に応じて タスクデータを送信する。ディスパッチャがマネージャプ ロセス経由でレシーバプロセスにタスクデータを送信しな
いのは, マネージャプロセスと他のクライアントプロセス との通信との競合を避け, 待機回数合計を最小化するため である。また, タスクデータは, 問い合わせ, および処理 結果のデータに比べて容量が大きくネットワークを混雑さ せるため, ディスパッチャは特定のサーバとのみ通信する。

ディスパッチャでは, あるタスクデータの送信後, 次の タスクデータの処理を行う。タスクデータの送信時点で直 前のタスクデータの送信が完了していない場合には，その タスクデータの送信が完了するまで待機し, 待機回数を 1 増加させる。

\section{2 .1 レシーバプロセス}

レシーバプロセスは任意のクライアントプロセスからの タスクデータを受信してキューに格納する。定義 3 に示し たようにサーバの負荷は割り当てられたタスク数, すなわ ちキューの使用量に比例する。レシーバプロセスは 3 機能 を持つ。第 1 はキューの使用量の管理とタスクデータの受 信である。レシーバプロセスのキューはあらかじめ与えら れた固定サイズで作成し, タスクデータを受信してこの 
キューに格納する。第 2 は, カリキュレータプロセスから のタスクデータ要求信号を受信して, キューからFCFSに 従ってカリキュレータプロセスにタスクデータを送信する ことである。 4.2 で示すタスクデータの処理時間 $105 \mathrm{~ms}$ は, このタスクデータの送信時間 $45 \mathrm{~ms}$ と, 検査処理時間 $60 \mathrm{~ms}$ からなる。送信後の夕スクデー夕は廃棄し, マネージャプ ロセスにキューの使用量を送信する。第 3 はマネージャプ ロセスからの終了信号受信である。

3.2 .2 カリキュレータプロセス

カリキュレータプロセスは, レシーバプロセスへのタス クデー夕送信要求とタスクデータの処理を繰り返す。1台 のサーバには複数のクライアントプロセスからタスクデー 夕が送信されるので, 処理結果は各クライアントプロセス ごとに線形リストとして保存する。レシーバプロセスから クライアントプロセスの終了信号を受信した場合，タスク デー夕処理結果を対応するクライアントプロセスに直接返 送する。レシーバプロセスにタスクデータの送信を要求し てもタスクデータを得られない場合には, あるランダムな 時間後に再度送信要求を発行する。

3.2 .3 マネージャプロセス

マネージャプロセスの機能は, クライアントプロセスか らのサーバ問い合わせに対する処理を行うことと, レシー バプロセスの負荷状況を管理することである。レシーバプ ロセスの負荷状況は, 3.2.1に示したように, それぞれの キューの使用量とする。クライアントプロセスからのサー バの問い合わせに対しては, 3.3 で述べる負荷均等化のアル ゴリズムに従ってサーバを決定し, その決定情報である サーバ番号をクライアントプロセスに返送する。

\section{3 負荷均等化}

クライアントプロセスの要求に対して, マネージャプロ セスは負荷均等化を目的関数としてサーバを決定する。こ こでサーバの負荷は定義 3 に示したように，割り当てられ たタスクの処理時間合計值である。サーバ決定の際には, その時点の通信可能性を優先して, さらに過去の割当回数 をむとにした発見的手法を適用する。アルゴリズムを次に 示す。

\section{【負荷均等化アルゴリズム】}

if（すべてのサーバが通信中） then

ランダムに1サーバを選択し，終了する；

for（通信中ではないすべてのサーバに対して）

キューの使用量が最小のサーバを求める;

if (求めたサーバ数が1) then

このサーバを選択し，終了する；

else

for（求めた複数個のサーバに対して）

これまでに割り当てた回数（割当回数合計）を求め る;

割当回数合計最小のサーバを選択し，終了する；
割当回数合計最小のサーバが複数個存在する場合に

は, ランダムに1サーバを選択し，終了する；

endif.

負荷均等化のアルゴリズムの考え方を述べる。まずタス クデータを送信可能なこと, すなわち通信中ではないこと である。通信中のサーバに通信を行おうとすると，通信時 間は通常の倍以上を要する (4.2参照)。さらに, キューの 使用量が最小のサーバを選択の対象とする。キューの使用 量とそのサーバの負荷とは比例するからである（定義3）。 Table 1 を使用してこの手法を説明する。まずサーバ $\boldsymbol{s}_{1}, \boldsymbol{s}_{3}$, $\boldsymbol{s}_{4}$ および $\boldsymbol{s}_{5}$ が選択の対象となる。これらのうちでキューの 使用量が最小のサーバ， $\boldsymbol{s}_{3}$ および $\boldsymbol{s}_{4}$ を選択する。サーバの 性能に差がある場合には, キューの使用量をサーバの相対 処理速度で割って負荷を正規化する。続いてこれまでの割 り当て回数の小さいサーバを選択するが，この例では両方 の割当回数が等しいことから $s_{3}$ と $s_{4}$ のうちランダムに一方 を選択してサーバとする。負荷均等化に関するこの手法の 性能は実験において評価する。

\section{4. 実験と評価}

提案する多重タスク割り当てアルゴリズムを実問題に対 して適用した実験と評価結果を述べる。

\section{1 多重タスク割り当てシステムの構成}

実験環境は, Table 2 に示す 16 台からなるPCクラスタで ある。これらをギガビットネットワークと 1 台の 16 ポート

Table 1. Status of servers

\begin{tabular}{lccccc}
\hline \multicolumn{1}{c}{ Server } & $s_{1}$ & $s_{2}$ & $s_{3}$ & $s_{4}$ & $s_{5}$ \\
\hline Used size of queue & 1 & 4 & 3 & 3 & 5 \\
Communication status* & 1 & 0 & 0 & 0 & 0 \\
Cumulative number of assignments & 5 & 2 & 4 & 4 & 1 \\
\hline
\end{tabular}

* Communication status 0: Idle, 1: Busy.

Table 2. Specifications of PC's in PC cluster

\begin{tabular}{|c|c|c|c|c|}
\hline No. & Machine name & MPU & $\begin{array}{c}\text { Clock } \\
\text { frequency } \\
(\mathrm{MHz})\end{array}$ & $\begin{array}{c}\text { Memory } \\
\text { size } \\
(\mathrm{MB})\end{array}$ \\
\hline 1 & $\mathrm{PC} 01$ & PentiumIII & 450 & 384 \\
\hline 2 & $\mathrm{PC} 02$ & PentiumIII & 450 & 384 \\
\hline 3 & PC03 & PentiumIII & 450 & 256 \\
\hline 4 & $\mathrm{PCO} 4$ & PentiumIII & 450 & 384 \\
\hline 5 & PC05 & Celelon & 433 & 256 \\
\hline 6 & PC06 & Celelon & 500 & 256 \\
\hline 7 & PC07 & Celelon & 500 & 256 \\
\hline 8 & $\mathrm{PC} 08$ & Celelon & 500 & 256 \\
\hline 9 & PC09 & Celelon & 500 & 256 \\
\hline 10 & $\mathrm{PC} 10$ & Athlon & 1300 & 256 \\
\hline 11 & PC11 & Celelon & 500 & 256 \\
\hline 12 & $\mathrm{PC} 12$ & Celelon & 466 & 256 \\
\hline 13 & $\mathrm{PC} 13$ & Celelon & 466 & 256 \\
\hline 14 & PC14 & Celelon & 466 & 256 \\
\hline 15 & PC15 & Celelon & 466 & 256 \\
\hline 16 & $\mathrm{PC} 16$ & Celelon & 500 & 1024 \\
\hline
\end{tabular}


スイッチングハブに接続する。オペレーティングシステム は検査プログラムの制約から Windows 2000, 開発言語は C，通信にはMPICH2-1.0.5, Windows 版11,12) 使用する。実 験では, ディスパッチャ数とサーバ数を変更して, 提案シ ステムとアルゴリズムの性能を評価する。

\section{2 評価データ}

実際の検查処理を対象とする。1タスクデー夕生成時間 $\boldsymbol{t}_{g}=40 \mathrm{~ms}, 1$ タスクの処理時間 $\boldsymbol{t}_{p}=105 \mathrm{~ms}, 1$ タスクデー夕 送信時間については，送信先が通信中ではない場合： $\boldsymbol{t}_{m}=24 \mathrm{~ms}$, 通信中の場合 : $\boldsymbol{t}_{m}=59 \mathrm{~ms}$, ディスパッチャ数 $2 \leq|D| \leq 5, \quad 1$ 製品検查に要する夕スク数 $|K|=1,000$, サー バファームサイズ $2 \leq|S| \leq 10$ とする。タスクデータ生成時 間, タスクの処理時間, および送信時間は, タスクデー夕 を 100 回処理して得られた時間の平均值であり，また数 $\mathrm{KB}$ のデータの送信時間は $1 \mathrm{~ms}$ 以下のため無視する。

\section{3 高速化と待機回数}

提案手法による高速化の評価を行う。ディスパッチャ数 を $2,3,4,5$ と変化させ, それぞれに対してサーバ数を可能 な限り増大させた。PCは, Table 2 におけるNo.1からNo. 6 までをディスパッチャと負荷管理サーバに, No. 7 から No. 16 までをサーバに使用する。例えば，ディスパッチャ数 2 の場合には, PC01, PC02をディスパッチャ, PC03を負荷管 理サーバ，そして PC07以下をサーバとする。結果を Fig. 6 に示す。図の縦軸が処理時間, 横軸がサーバ数, ディス パッチャ数 $(|D|)$ を 2 から 5 まで変化させた場合の処理時間 の削減を示している。

ディスパッチャ 1 台とサーバ 1 台を直結した逐次処理の 場合の 1 製品の検査処理時間は, (第 1 タスクの生成時間) +(第1タスクの送信時間 $)+$ (全夕スクの処理時間) + (待 機タスクの処理時間 $)=0.040+0.024+0.105 \times 1,000+0.105 \times$ $390=146.0$ 秒となり, 実測值も送信時間のばらつきの範囲 でこの值に近い結果となった。待機タスクの処理時間で示 されている $0.105 \times 390$ は，ディスパッチャで 1,000 個の夕ス クデータ生成が終了した時点でキューに残っているタスク を処理するための時間である。Fig. 6ではサーバ数がいず れの場合でも, 処理時間は逐次処理の場合よりも高速であ る。また，ディスパッチャ数 2 と 3 の場合には，それぞれ サーバ数 6 と 8 の時点で, タスクデータ生成時間合計であ る 40 秒に近い 43.1 秒と 42.8 秒の処理時間を達成している。 ディスパッチャ数に対する処理時間の削減結果を指数関数 近似した式を図中に示している。特にディスパッチャ数 4 と 5 の場合には, PCクラスタの台数からサーバ数 10 まで実 験のみが可能であった。近似式によれば，それぞれサーバ 数 11,13 以上であれば処理時間を約 40 秒に削減すること が可能であると予想される。

続いて, 同一条件における待機回数の実験結果を Fig. 7 に示す。すでに述べたように，待機したタスクデー夕は $40 \mathrm{~ms}$ 後に改めてサーバに送信しなければならず, 全夕ス

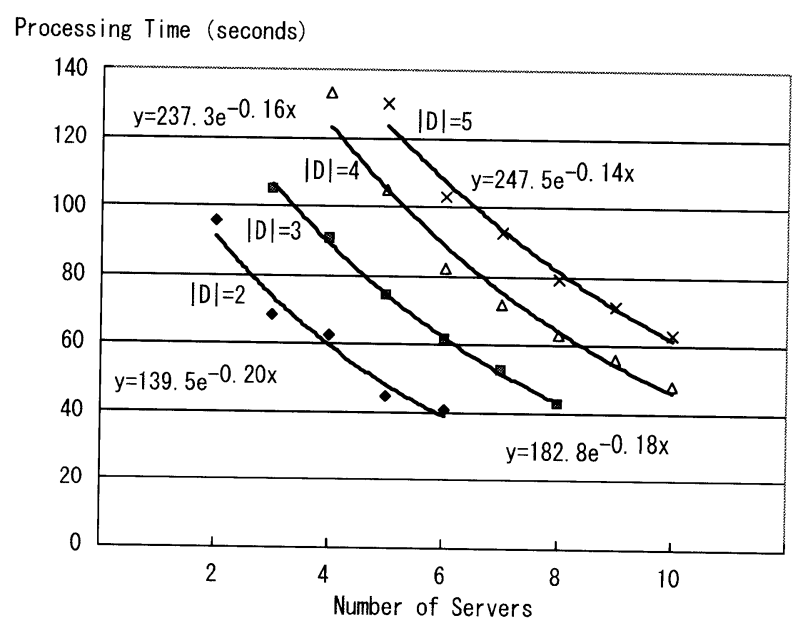

Fig. 6 Speed-up of suggested parallel process

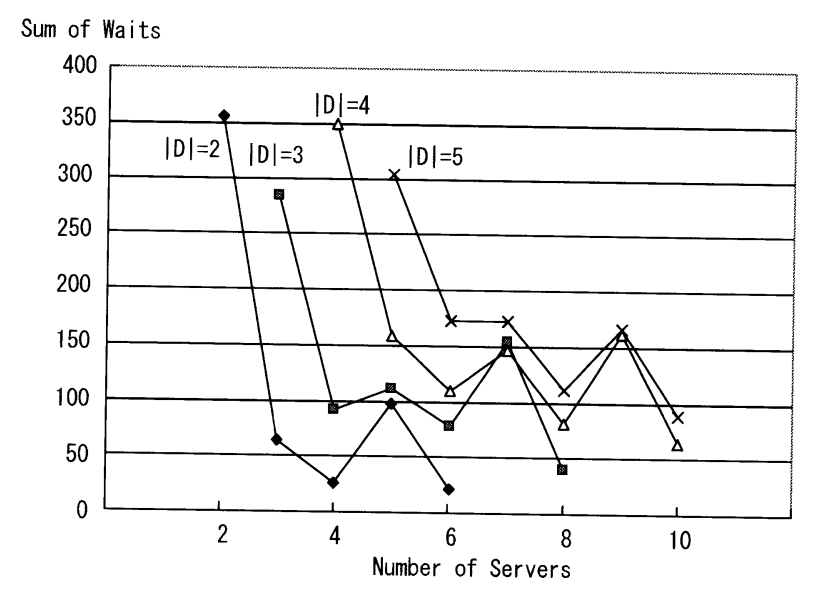

Fig. 7 Sum of waits vs. number of servers

ク数は, 生成タスク数と待機タスク数の和になる。

Fig. 7 に示すように, 本並列分散手法では, サーバ数が ある程度以上になれば, 待機回数を逐次処理の 1 ディス パッチャ当たり 390 回から大きく削減できているが, 回数 自体は大きな変動を持つ。これは, PC クラス夕を構成する $\mathrm{PC}$ が接続を維持するために本検査処理とは無関係の通信 を不定期的に行っているためと推定される。実際に, 実験 の途中でネットワークの通信量が急激に增大することが あった。Fig. 6 とFig. 7 から, 待機回数が 1 ディスパッチャ 当たり, 10 回程度に削減されないと, 処理時間を約 40 秒 に近づけることは困難であると思われる。実際に, ディス パッチャ数(|D|) 2 と 3 では, それぞれ 1 ディスパッチャ当 たりの最小待機回数が 11 と 13 である。

\section{4 負荷均等化}

負荷均等化に関する評価結果をFig. 8 に示す。定義 4 に 示したように, 本論文では定義 3 に示す負荷の標準偏差を 最小化する。Fig. 8では, 縦軸に標準偏差である $F_{1}$ の值 （定義 4, 式(1)), 横軸にサーバ数を示している。標準偏差 はディスパッチャ数とサーバ数に関して, 特に相関は見ら れない。また標準偏差の值は, 最大で $20 \%$ 程度となってい 
Standard Deviation (\%)

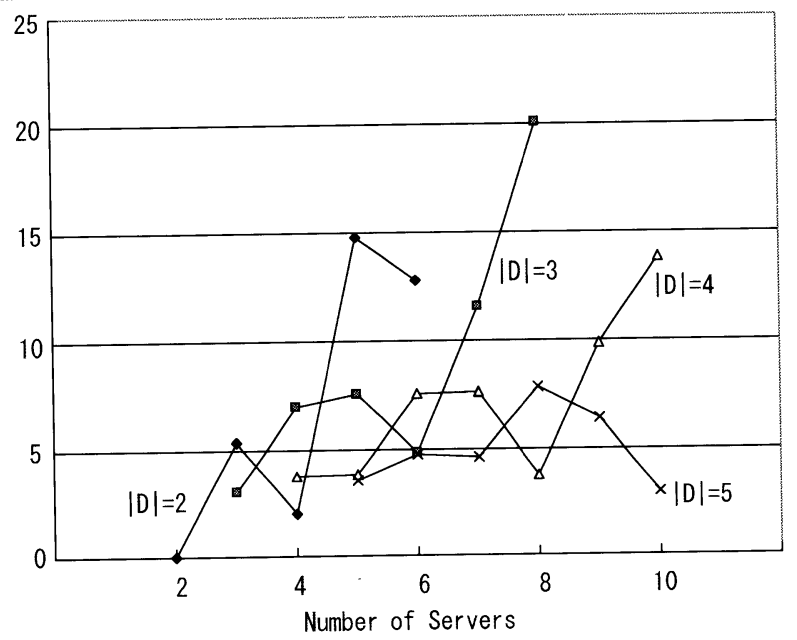

Fig. 8 Standard deviation of loads vs. number of servers

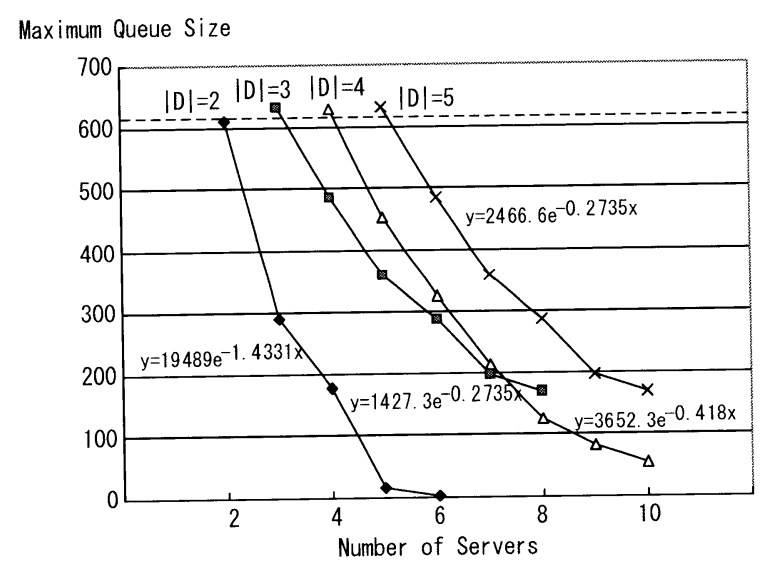

Fig. 9 Maximum queue sizes vs. number of servers

る。これは，3.3で示したように，提案アルゴリズムが，負 荷均等化よりもサーバが通信中か否かを優先してタスク デー夕を割り当てているためであると考えられる。

\section{5 サーバにおけるキューのサイズ}

1節で示したように，逐次処理ではサーバのキューのサ イズは最大 618 になる。提案システムと提案アルゴリズム によるサーバのキューのサイズ削減について評価した。Fig. 9 に示すように，ディスパッチャ数に対してサーバ数があ る程度以上でないとキューのサイズは削減できない。困の 破線が逐次処理の場合の 618 を示すが，ディスパッチャ数 がいずれの場合でも，高速化の効果が得られるサーバ数 (例えば， $|D| \times 2+2$ ) 以上であれば，キューのサイズを推 定值を含めて 4 から 168 までの間に削減することができる。

本実験において，ディスパッチャ数に対してサーバ数を どの程度にすれば良いかについては理論的な解析は困難で あったが，評価の結果，少なくとも $(|\mathrm{D}| \times 2+2)$ 台以上で あれば，下限值に近い高速化と 4 分の 1 に近い省メモリ化 の効果が得られると考えられる。

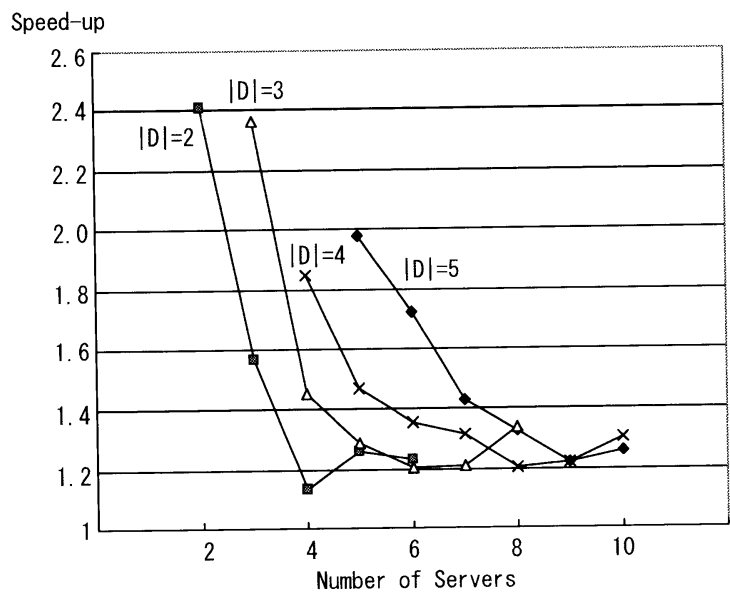

Fig. 10 Speed-up of suggested method over random method; The speed-up is calculated by the expression, $R=$ (Processing Time of Random Method)/(Processing Time of Suggested Method).

\section{6 ランダムタスク割り当てアルゴリズムとの比較}

\section{6 .1 処理時間の比較}

並列分散処理において負荷管理サーバを利用せず，ディ スパッチャがタスクデータをランダムにサーバに割り当て るアルゴリズムをプログラム化し，提案する多重夕スク割 り当てアルゴリズムと比較した。

Fig. 10 に多重タスク割り当てアルゴリズムの処理時間を ランダム割り当てアルゴリズムの処理時間で除した高速化 の結果を示す。縦軸はその高速化, 横軸はサーバ数で, ディスパッチャ数にかかわらず，サーバ数が増大するに 従って高速化の倍率は減少する。これは, 多重夕スク割り 当てアルゴリズムの処理時間が下限值の 40 秒に近づくこと と, ランダム割り当てアルゴリズムでもサーバ数が増えれ ば，処理時間に関しては, ある程度の短縮が可能であるた めと考えられる。

\subsection{2 所要メモリ量の比較}

所要メモリ量は最大キューサイズと関連する。多重タス ク割り当てアルゴリズムとランダム割り当てアルゴリズム の最大キューサイズを比較した。Fig. 11 に, サーバ数に対 する最大キューサイズの比較結果を示す。縦軸はランダム 割り当てアルゴリズムの最大キューサイズを多重タスク割 り当てアルゴリズムの最大キューサイズで除した值,横軸は サーバ数である。ディスパッチャ数が 2 から 5 のいずれに 対しても, サーバ数が増大するに従って最大キューサイズ は $17 \%$ から $99 \%$ まで削減可能であった。

\section{6 .3 逐次処理と並列処理の比較}

ここまでは，サーバ数と各性能の関連を評価した。ここ ではディスパッチャ数 2 , その場合に最大効果を得られる サーバ数6の場合に対して, 並列処理における多重タスク 割り当てアルゴリズムとランダム割り当てアルゴリズム, および逐次処理に対して各性能を比較した。評価結果を 


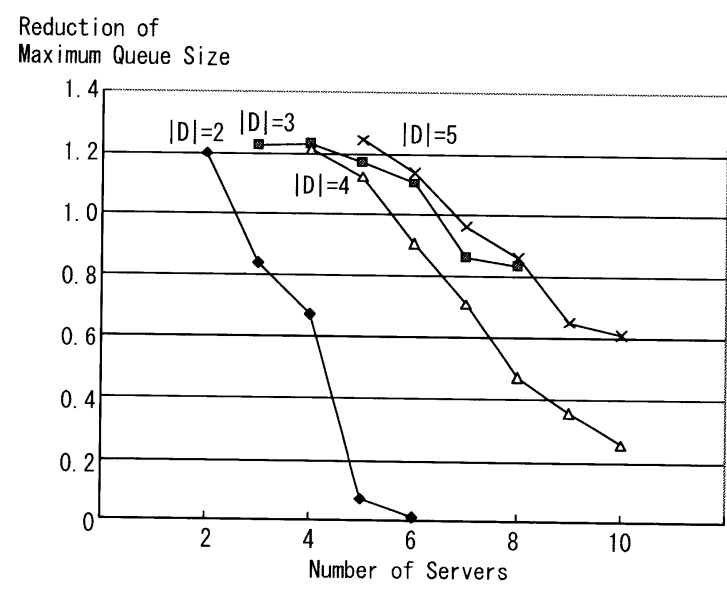

Fig. 11 Reduction ratio of maximum queue size of suggested method over random method; The reduction ration is calculated by the expression $E=$ (Maximum Queue Sizeof Random Method)/ (Maximum Queue Size of Suggested Method).

Table 3. Comparison of performances among three methods

\begin{tabular}{lccc}
\hline & \multicolumn{2}{c}{ Parallel process } & \\
& $\begin{array}{c}\text { Suggested } \\
\text { method }\end{array}$ & $\begin{array}{c}\text { Random } \\
\text { method }\end{array}$ & $\begin{array}{c}\text { Sequential } \\
\text { process }\end{array}$ \\
\hline Processing time (sec) & 40.8 & 50.3 & 146.0 \\
$\begin{array}{l}\text { Number of waits } \\
\begin{array}{l}\text { Standard deviation of loads } \\
(\%)\end{array}\end{array}$ & 21 & 288 & - \\
Maximum queue size & 12.8 & 7.5 & - \\
\hline
\end{tabular}

Number of dispatchers: 2, Number of servers: 6 .

Table 3 に示す。多重タスク割り当てアルゴリズムでは，処 理時間を逐次処理の 146.0 秒から 40.8 秒へと $72 \%$ 削減，待 機回数（定義 4, 式(2)）はランダム割り当てアルゴリズム の 288 から 21 へと $93 \%$ 削減, 負荷分散に関してはランダム 割り当てアルゴリズムの 7.5 から 12.8 と 1.7 倍に増大させた が，所要メモリ量（最大キューサイズ）は，166から2へ と $99 \%$ ，逐次処理の 618 からは $99.7 \%$ ，それぞれ削減して いる。一例の結果であるが，これまでの評価結果と合わせ て, 並列処理は逐次処理よりも高速化と省メモリ化を達成 可能で, 提案する多重タスク割り当てアルゴリズムはラン ダム割り当てアルゴリズムと比較して, 高速化之省メモリ 化の点でさらに高性能であると言える。

\section{5. 結 論}

製品検査処理の並列分散化に関して，多重夕スク割り当 て問題を定義し，それを解くためのディスパッチャ, サー バ，負荷管理サーバからなる多重夕スク割り当てシステム を構築し，多重タスク割り当てアルゴリズムを提案した。
実験評価の結果，ディスパッチャに対してある台数以上の サーバを与えることにより，製品検查の夕スク生成時間に 近い処理時間と，逐次処理に対して所要メモリ量を少なく とも 4 分の 1 程度に削減させることが可能なことを示した。 今後は，検查処理時間など，条件の異なる製品検査処理に 対して, 提案する並列分散処理による高速化と所要メモリ 量削減を検討する。

(2007.2.19-受理)

\section{文献}

1) 岡田佑樹, 白石洋一: “動的負荷分散機能を持つ並列シ ミュレーションプラットフォーム”，エレクトロニクス実装 学会, 第 19 回学術講演大会, 2004.3

2) B. Schroeder and M. Harchol-Balter: "Evaluation of Task Assignment Policies for Supercomputing Servers: The Case for Load Unbalancing and Fairness", Proceedings of HPDC 2000, pp. 211-219, 2000

3) M. Harchol-Balter: "Task Assignment with Unknown Duration”, Journal of the ACM, Vol. 49, No. 2, pp. 260-288, 2002

4) M. Harchol-Balter, C. Li, T. Osogami and A. Scheller-Wolf: "Cycle Stealing under Immediate Dispatch Task Assignment", Proceedings of SPAA 2003, pp. 274-284, 2003

5) Y. Azar, A. Z. Broder and A. R. Karlin: "On-Line Load Balancing”, Proceedings on Computer Science, ACM, pp. 218-225, 1992

6) V. S. Iyengar, L. H. Trevillyan and P. Bose: "Representative Traces for Processor Models with Infinite Cache”, Proceedings of the 7th International WWW Conference, 1998

7) M. S. Squillante, D. D. Yao and L. Zhang: "Web Traffice Modeling and Web Server Performance Analysis", Proceedings of the IEEE Conference on Decision and Control, 1999

8) K. W. Ross and D. D. Yao: "Optimal Load Balancing and Scheduling in a Distributed Computer System", Journal of the ACM, Vol. 38, No. 3, pp. 676-690, 1991

9) F. Bonomi and A. Kumar: "Adaptive Optimal Load Balancing in a Nonhomogeneous Multiserver System with a Central Job Scheduler", IEEE Trans. on Computers, Vol. 39, No. 10, pp. 1232-1250, 1990

10) L. D. Eager, E. D. Lazowska and J. Zahorjan: "Adaptive Load Sharing in Homogeneous Distributed Systems", IEEE Trans. on Software Eng., Vol. SE-12, No. 5, pp. 662-675, 1986

11) P. パチェコ（秋葉博訳）：“MPI並列プログラミング”, 培風 館, 2001.7

12) Argonne National Laboratory: MPICH, http://www-unix.mcs. anl.gov/mpi/mpich2/ 